\title{
Katarzyna Chtapek
}

\section{The Types of Business Risk Identified in Integrated Reporting}

\begin{abstract}
The paper presents the possibilities of identifying business risk on the basis of data disclosed in integrated reporting. The research method used relies on a review of Polish and foreign literatures and an empirical analysis of integrated reports disclosed in 2016. The structure of the reports, which complies with the most recent trends and international recommendations with regard to integrated reporting, confirms the hypothesis put forward in the paper. The concluding remarks aim to arouse interest in research on the possibilities of verifying and assessing disclosures related to the identification of risk in integrated reporting.
\end{abstract}

Keywords: integrated reporting, business risk, business risk identification, integrated report.

JEL Classification: G32.

\section{Introduction}

The obligation to present information on business risk in financial reporting is set forth in the legal systems of a number of European countries as well as EU regulations (Directive 2014/95/EU). The above standards require entities, among others, to identify risk management factors and methods. The proposed structure of integrated reporting, reflecting the efforts aimed at unifying and, to some 
degree, aggregating reported information, also points to the necessity of carrying out analyses in the area of identifying business risk.

This study aims to identify business risks companies present in their integrated reporting (IR), which are available on the websites of the International Integrated Reporting Council (IIRC), which provide guidelines for companies which take up the challenge of generating reports in the subsequent periods of their operations, encouraging them to continue research on the quality and effective verification of disclosed information.

The main hypothesis is that integrated reporting can be a source of information on identifying business risk, hence the research objective of the work is to analyse data presented in integrated reports.

The basic research method relies on a long-lasting and in-depth analysis of the evolution of financial reporting and the verification of trends observed in business practice. The study includes a review of Polish and foreign literature in the field of integrated reporting and business risk. It refers to the results of studies the author has done on identifying and measuring business risk, including those based on integrated reporting in Polish listed companies (Chłapek 2016, pp. 76-93). In the further part of the study, an empirical analysis of integrated reports generated by entities in 2011-2016 is presented, with special attention given to the identification of business risk in 2016. The study is based on an analysis of a sample of integrated reports from IIRC websites.

The work aims to arouse interest in disclosures concerning business risk presented in integrated reporting.

\section{Integrated Reporting in the Practice of Economic Entities}

In the era of globalisation, and in the context of problems related to business risk, accounting systems and, consequently, financial reporting are subject to continuous changes. The data which are presented on an entity's achievements have, over the course of years, undergone various modifications, shifting from strictly financial, quantitative and verifiable data towards comprehensive non-financial disclosures presented in a narrative form. This process reflects the trend to adjust the development of accounting to the needs of a wide range of recipients (Andrzejewski 2016, p. 20), necessitating an entry into newly identified fields - the subsequent stages of the development of financial accounting, characterised by increasingly sophisticated areas of knowledge and technology. The current conditions of integration and the requirements related to advanced forms and tools, as well as the development of automation, computerisation and electronisation imply the need for continuous progress. This indicates that even a highly aggregated 
report - an integrated report - is certainly not the last stage of developing financial reporting, constituting a challenge for research in the field of economic entities' financial reporting.

Integrated reporting is the most current response to the needs of the recipients of accounting information as well as to the analyses of entities' reports and the diversified character reflected in their form and scope (financial statements, reports on management activities, annual report, environmental report, social report, sustainable development report, etc.). The combination of financial information, presented separately in a financial statement as a report of management board activities and as other non-financial information, included in various types of thematic reports, makes it possible to provide a large number of recipients with a comprehensive, reliable, transparent and comparable view of an entity's overall activities. Consequently, stakeholders' expectations are met with regard to an entity's responsibility for its activities and its impact on the environment, presented through the reliable reporting of information on the effectiveness of business activities and the possible measures aimed to counteract business risk and mitigate its effects (Eljasiak 2011, p. 100).

Integrated statements are intended to present a more transparent picture of information on an entity's activities and achievements, representing a new approach to corporate reporting - an issue which is widely discussed in Polish and foreign literatures (Krasodomska 2015). The integrated reporting framework is also a leading topic of numerous scientific conferences, including Polish annual congresses of university accounting departments, and a meeting organised by IIRC, entitled "The Official Integrated Reporting Convention". Such events aim to exchange experience and identify prospects for integrated thinking $-\mathrm{a}$ foundation of IR. Dialogue for longer-term value creation, and IIRC along with the International Corporate Governance Network (ICGN) are scheduled to cover other continents. For example, a conference is to be held in Tokyo in 2018 under the same title (http://integratedreporting.org/, accessed: 15.08.2017). Currently, IIRC is a leading organisation promoting IR implementation. However, the concept itself originates from South Africa, where guidelines for integrated reporting were set forth prior to the establishment of IIRC (de Villiers, Rinaldi \& Unerman 2014, p. 2). Integrated reporting is currently viewed as a call for integrated thinking, planning and reporting of entities' performance which aims to increase their financial results and, consequently, their value. In a number of countries, proposals have been set forth to transform integrated reporting into integrated information management, which represents a continued evolution of reporting and constitutes another challenge for accounting systems (Kraten 2017, pp. 6-9).

In accordance with the fundamental concepts described in The International IR Framework (2013), an integrated report aims to present and explain an entity's 
overall activities in the context of creating value for its owners. An appropriated presentation of data is guided by the following fundamental guidelines:

1) strategic focus and future orientation - a report should provide insight into an entity's strategy (in this context, an entity's ability to create value should be presented over short-, mid- and long-term horizons);

2) connectivity of information - it is required to present an overall view of mutual relations and contingencies among the factors affecting an entity's ability to create value over time;

3) stakeholder relationships - IR should provide insights into the nature and quality of an entity's relationships with its key stakeholders, including the manner in which an entity understands, considers and responds to stakeholders' justified needs and interests;

4) materiality - it is obligatory to disclose information on the issues which have a material impact on an entity's ability to create value;

5) conciseness - an effort is made to present information concisely;

6) reliability and completeness - all significant factors, both positive and negative, should be presented in a balanced manner and without significant errors;

7) consistency and comparability - information should be presented consistently over time, ensuring its comparability with that of other entities.

According to IIRC proposals, the general structure of an integrated report should be composed of 8 elements, which are correlated and not mutually exclusive (Fig. 1).

The benefits resulting from the structure presented by the IIRC include: strong transparency, the possibility of disclosing how all types of capital are managed, an integrated approach to business, a reader's focus on past events and referred to the future, and the conciseness and materiality of information disclosed in an integrated report (Bek-Gaik 2015 p. 486). In analysing the content of IR, the literature points to well-structured and consistent information, transforming the most significant financial and non-financial data into a coherent whole (Bek-Gaik \& Rymkiewicz 2015, p. 65). Another visible benefit is the increased comparability and reliability of disclosures, which may ultimately lead to the obligation to adopt integrated reporting at the EU level (Lambooy, Hordijk \& Bijveld 2014, pp. 217-224).

IR has also come in for a good deal of criticism. J. Brown and J. Dillard (2014, pp. 1122-1156) state that IIRC guidelines with regard to the assessment of and reporting on sustainable development are one-sided and limited. Significant controversy is also caused by the presentation of financial data, indicating the need for further research to identify major shortcomings (Kwiecień 2016; Kędzior 2016). B. Micherda has observed: "Whatever stores you issue, do it by number and weight, spendings and takings, put everything in writing" (Mqqdrość... 1991, p. 83; Podstawy... 2005, p. 11). A response to this criticism is that the recipients 


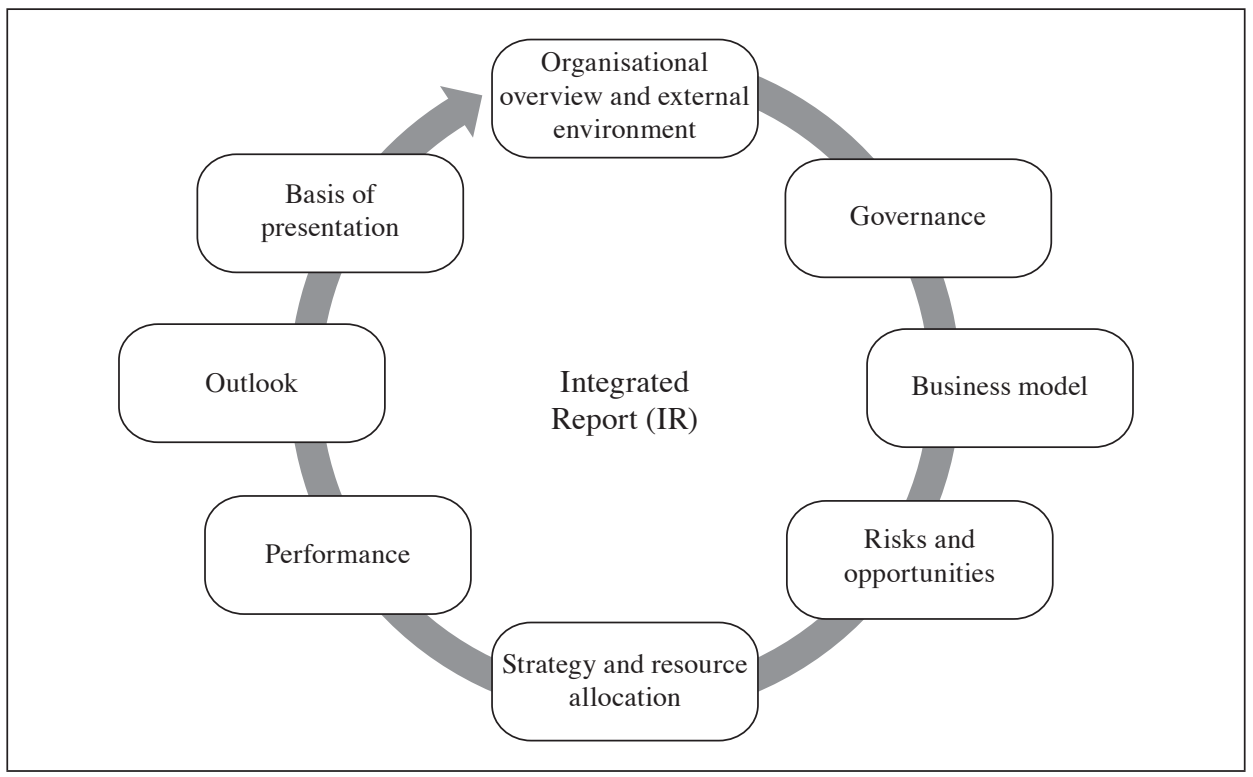

Fig. 1. Content Elements of Integrated Report

Source: the author, based on (The International IR Framework 2013).

of reports should encourage entities to identify in their reporting correlations between financial and non-financial information (Zicari 2014, pp. 201-220).

A number of authors have attempted to analyse data disclosed in integrated or other reports based on their structure, pointing both to benefits and threats related to IR. Analysis of the literature leads to the conclusion that integrated reporting poses a great challenge for accounting systems in a number of areas. Moreover, the above analysis points to the need for further analysis of risk within the framework of issues discussed in this work.

\section{The Place of Business Risk in Integrated Reporting}

The literature defines business risk in a number of ways. The widely accepted ones include:

- risk is a condition resulting from the existence of uncertainty (Black 2008, p. 426),

- risk is the possibility of an unexpected effect occurring (Jajuga \& Jajuga 1996, p. 99),

- risk indicates that future events will result in cash flows with a known probability distribution (Szychta 2010, p. 742). 
While the terms risk and uncertainty are commonly regarded as synonymous, they can be differentiated. In 1901, A. H. Willett (Urbanowska-Sojkin 2013, p. 19) analysed and identified uncertainty and risk on a scientific basis, defining uncertainty as a subjective reception of the state of the environment, resulting from human deficiencies and the imperfection of the knowledge of the laws that govern reality. He viewed risk as an objective state of the external world, correlated with subjective uncertainty. According to F. H. Knight, risk can be differentiated from uncertainty on the basis of differences between a measurable and non-measurable uncertainty (Karmańska 2008, p. 29-30). According to the above assumptions, uncertainty is defined as a non-measurable uncertainty, while risk represents a quantifiable form of uncertainty. In this context, special attention should be given to P. Bromiley's, K. D. Miller's and D. Rau's interpretations, which bring the definition of uncertainty and risk directly into a business context, defining uncertainty as the unpredictability of events inside and outside an entity. Risk, in turn, in the context of strategic management, is the unpredictability of the results of specific undertakings related to revenue, costs, profit and market share (Bromiley, Miller $\&$ Rau 2001). In light of the above considerations, two concepts of risk can be defined: exclusively threats, in accordance with the negative concept of risk, and opportunities and threats, in light of the neutral concept of risk (Zarzqdzanie... 2008, p. 13).

The interest that exists in the international arena in management risk tools and methods, reflected in the development of risk management standards including FERMA, COSO II, AS/NZS, attests to the significant role which business risk plays. Those standards define business risk on the basis of neutral risk, which considers both threats and opportunities resulting from risk. Because of the ubiquitous character of risk in business activities and the dynamic occurrence of new risk areas, it is necessary to assess both current and future threats (Lai, Azizan \& Samad 2009, p. 44). With regard to management, an emphasis is laid on the role of threats related to risk and the need to transform them into opportunities both in development projects and an entity's current operations (Merchant 2012, p. 32).

Any economic event requires an accurate identification of its potential determinants. A proper identification of risk should be a continuous process comprising various aspects and areas related to an entity's overall activities. An appropriate identification results in developing a comprehensive list of potential types of risk which are significant from the perspective of an entity's unique character and its functioning (Rogowski \& Michalczewski 2005, p. 19; Khattab 2011, p. 275). Various types of risk faced by economic entities have been defined (Chłapek 2015, pp. 19-25). However, special attention should be given to the classification proposed by K. Jajuga (Zarzqdzanie... 2008, pp. 18-25), which defines types of 
financial risk - the factors which have a financial impact on a business entity. They include the following:

1) market risk - results from price changes in financial markets and related markets, for example the commodity market. Types of market risk include:

- exchange rate risk,

- interest rate risk,

- stock price risk,

- commodity price risk,

- real estate price risk

- property price risk;

2) credit risk is identified on the basis of the following criteria:

a) credit risk understood in a broad sense:

- default risk,

- creditworthiness risk,

b) types of credit risk:

- borrower risk or issuer risk,

- counterparty risk;

3) operational risk: internal and external fraud, work safety and relationships with employees, customers, products and business relationships, damage to physical assets, system deficiencies, and business process management;

4) liquidity risk: the possibility of converting assets to cash over short periods of time and at a fixed price, solvency risk and liquidity risk related to financial market transactions;

5) legal risk;

6) business risk;

7) event risk;

8) model risk.

The above classification of types of risk meets all the requirements of an analysis of an entity's business risk.

The issue of reporting information on risk in financial statements is widely discussed by analysts, who point to the lack of legal regulations which would require business entities to disclose relevant data (Sikacz 2014, pp. 719-729). The results of such analyses are confirmed by those who depend on financial reporting who frequently complain about the lack of sufficient information on business risk in entities' financial reporting.

Integrated reporting puts a strong emphasis on the problem of business risk. An element of the content of IR is "risks and opportunities", which, according to the IIRC guidelines, should identify specific risks and opportunities affecting an entity's ability to create value over a short-, mid- and long-term horizon. IIRC recommendations also call for the "outlook" section to present data that will help 
to identify business risk. This section includes information on challenges and uncertainties an entity can face in the course of implementing its strategic plans.

\section{An Analysis of the Scope of Business Risk Identification in Integrated Reporting}

I carried out a preliminary analysis of all integrated reports disclosed on IIRC's website as of 20 August 2017 (http://examples.integratedreporting.org/ search? $\mathrm{x}=22 \& \mathrm{y}=18 \&$ organisation_type=\&organisation_region=\&organisation industry $=\&$ report_type $=\&$ report_year $=2016 \&$ fragment_content $=2$, accessed: 20.08.2017). All the selected reports meet IR requirements, regardless of their specific names. The reports present the data of companies listed on world stock exchanges, representing various business activities, and divided into 13 sectors. The analysed time framework is affected by limitations resulting from a relatively short period of IR adoption, covering the years 2011-2016. Fig. 2 presents the number of reports per year.

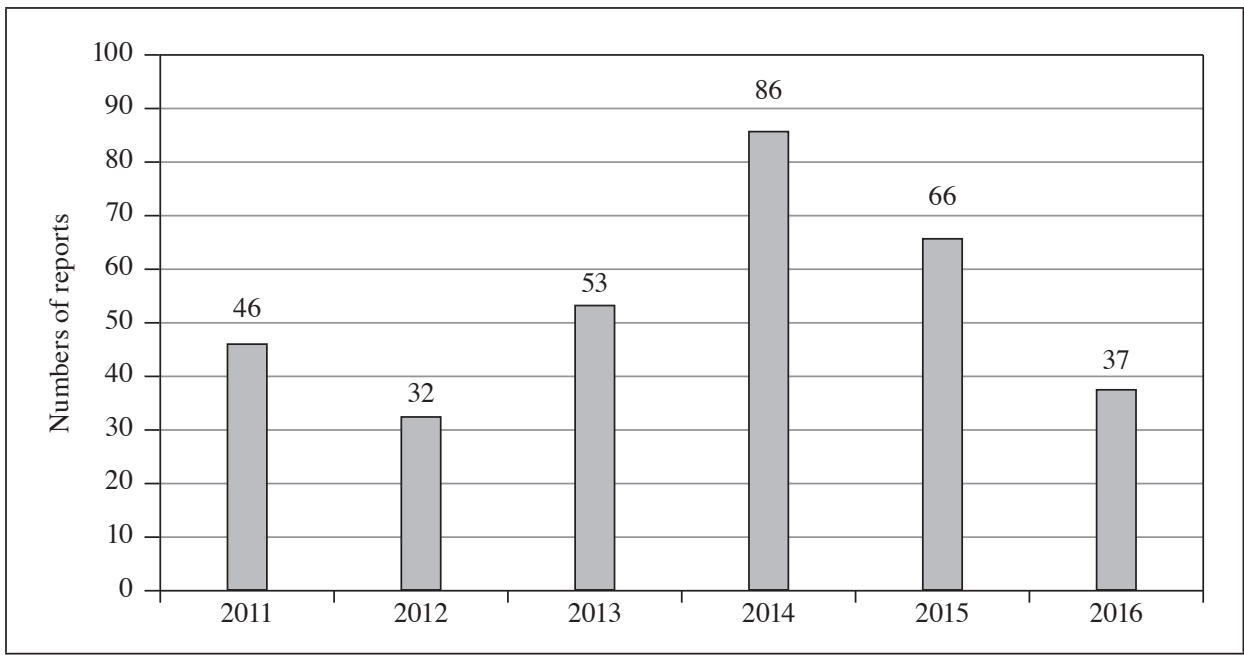

Fig. 2. The Number of Integrated Reports Disclosed on IIRC's Website, 2011-2016 Source: the author's research.

Analysis of the data shows an increasing interest in putting out reports complying with IIRC guidelines. However, despite an initial increase in the number of reports complying with the requirements (up to 86 reports in 2014), the number fell to 66 a year later, then all the way to 37 in 2016. The drop was 
mainly attributable to the fact that reporting according to IIRC guidelines is not mandatory. Such reporting is also a time-consuming process entailing numerous dilemmas, while people responsible for the synthetic presentation of financial and non-financial information are not always fully competent. The formula of an integrated report poses a number of challenges, requiring its authors to adopt an interdisciplinary approach and demonstrate professional skills. Table 1 presents a matrix of randomly selected companies which decided to prepare IRs and disclose them on the IIRC's website. The table presents a zero-one matrix which reflects IR(1) or its absence IR (0) on IIRC's website in 2011-2016.

Table 1. Companies Disclosing IR in 2011-2016

\begin{tabular}{|l|c|c|c|c|c|c|}
\hline \multicolumn{1}{|c|}{ Name of Entity } & 2011 & 2012 & 2013 & 2014 & 2015 & 2016 \\
\hline ACCA & 0 & 1 & 0 & 1 & 0 & 1 \\
\hline BP & 0 & 0 & 0 & 1 & 0 & 0 \\
\hline CIMA & 0 & 1 & 1 & 1 & 0 & 0 \\
\hline DIAGEO & 1 & 0 & 0 & 0 & 0 & 1 \\
\hline EXXARO & 1 & 1 & 1 & 0 & 0 & 0 \\
\hline FIBRIA & 1 & 0 & 0 & 0 & 1 & 0 \\
\hline GOLD FIELDS & 1 & 1 & 1 & 1 & 1 & 0 \\
\hline G4S & 0 & 0 & 0 & 1 & 0 & 0 \\
\hline IBEDROLA & 0 & 0 & 0 & 1 & 0 & 1 \\
\hline JSC TVEL & 0 & 0 & 0 & 1 & 0 & 0 \\
\hline LAWSON & 0 & 0 & 1 & 0 & 0 & 0 \\
\hline MONDI & 0 & 0 & 0 & 0 & 0 & 1 \\
\hline NORDGOLD & 0 & 0 & 0 & 0 & 1 & 0 \\
\hline NATURA & 1 & 0 & 0 & 1 & 0 & 0 \\
\hline PHILIPS & 0 & 0 & 0 & 0 & 1 & 0 \\
\hline SAP & 0 & 0 & 0 & 0 & 1 & 0 \\
\hline TITAN & 0 & 0 & 0 & 1 & 0 & 0 \\
\hline UNILEVER & 1 & 1 & 1 & 1 & 0 & 0 \\
\hline VODACOM & 1 & 1 & 1 & 0 & 1 & 1 \\
\hline XSTRATA & 1 & 0 & 0 & 0 & 0 & 0 \\
\hline SO & & & & & & \\
\hline
\end{tabular}

Source: the author's research.

The information presented indicates that none of the entities prepared an IR for each fiscal year (Vodacom - the absence of IR in 2014, and Gold Fields - the absence of IR in 2016). Due to the lack of the obligatory character of disclosures and time requirements, entities prepare IRs to suit their individual strategies.

The next stage of the analysis considers the presence of risk issues (risks and opportunities) in IRs. Trends in this area are described on the basis of the share 
(\%) of integrated reports containing this element in the total number of IR disclosures in a given year (Fig. 3).

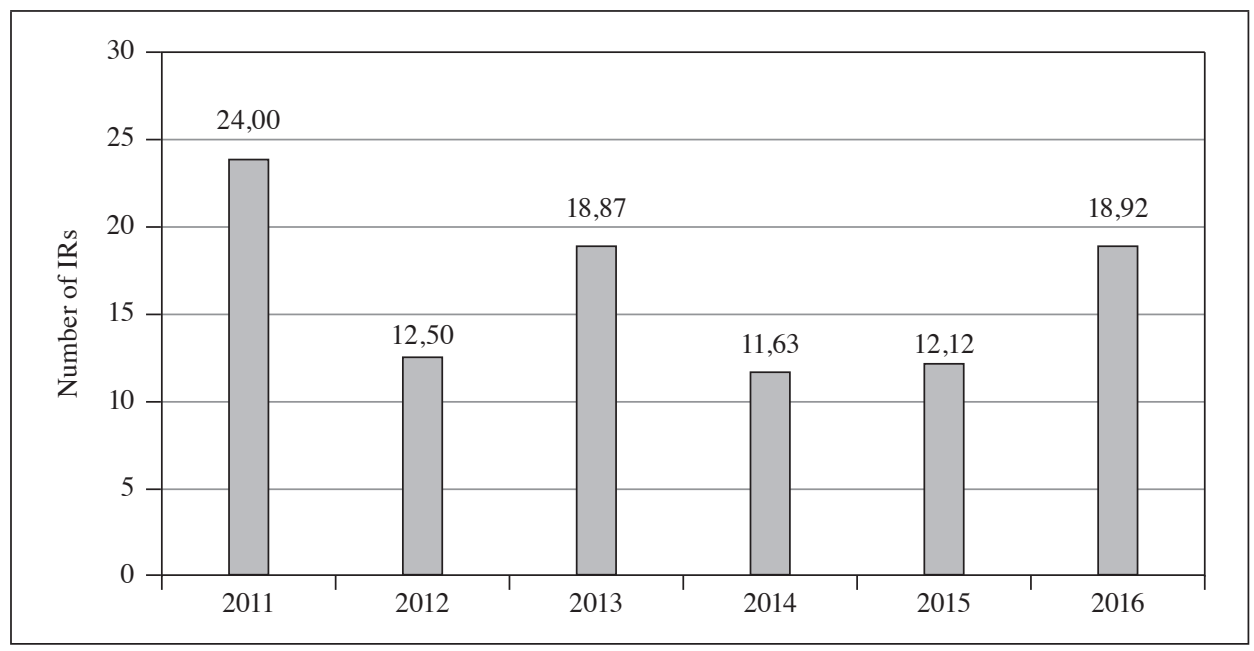

Fig. 3. The Number of IRs Including the Content Element "Risks and Opportunities" in 2011-2016 (\%)

Source: the author's research.

Fig. 3 indicates that, apart from an increasing interest in presenting reports according to IIRC guidelines, only a few of the statements included the recommended element "risks and opportunities". An analysis of the current trends indicates that reports in 2011 met IIRC requirements to a greater extent (24\% of published IRs), while the respective figure for 2014 was below 12\%. IRs in 2016 paid more attention to identifying business risk with regard to the previous two years - nearly $19 \%$ of them include this element. In the context of explaining the above correlations, the existing trends may seem surprising, especially because of the increasing significance of risk identification on a global scale in both the micro- and macroeconomic dimensions. This is undoubtedly because the disclosures are not required by law and a reluctance to maintain risky policies (unlike in the several years that followed the global crisis). Moreover, not all entities describe the content of their reports appropriately, so though they do identify risks, such reports cannot be disclosed in accordance with IIRC requirements. A detailed analysis of the remaining content elements in IR is presented in Deloitte's December 2016 report, Integrated Reporting Moving towards Maturity. Are We Truly Maximizing the Benefits of Integrated Reporting? (2016).

Further analysis here is based on all IRs disclosed in 2016, which include the content element "risks and opportunities", as part of a review of disclosures related 
to business risk. The following entities included risk-related information in their 2016 reports prepared in accordance with IIRC guidelines: AXA, Coca-Cola Hellenic Bottling Company, Diageo, ING, Ibedrola, Novo Nordisk, and Tata Steel.

Table 2 presents the basic IR-related information about these companies and detailed data on IT disclosures from IIRC's website in 2011-2015 (in 2016, all the entities in Table 2 disclosed IRs). The information presented is based on the zero-one system - the presence of disclosure IR (1), or its absence IR (0).

Table 2. Basic Information about Companies which Disclose "Risks and Opportunities" in Their IRs in 2016

\begin{tabular}{|l|c|c|c|c|c|c|c|c|}
\hline \multirow{2}{*}{ Name of Entity } & Region & Sector & 2011 & 2012 & 2013 & 2014 & 2015 & $\begin{array}{c}\text { IR in } \\
\text { (pages) }\end{array}$ \\
\cline { 4 - 8 } & Europe & $\begin{array}{c}\text { financial } \\
\text { services }\end{array}$ & 0 & 0 & 0 & 0 & 1 & 102 \\
\hline AXA & Europe & $\begin{array}{c}\text { consumer } \\
\text { goods }\end{array}$ & 0 & 0 & 1 & 0 & 1 & 216 \\
\hline COLA-COLA HBC & Europe & $\begin{array}{c}\text { consumer } \\
\text { goods }\end{array}$ & 1 & 0 & 0 & 0 & 0 & 160 \\
\hline ING & Europe & $\begin{array}{c}\text { financial } \\
\text { services }\end{array}$ & 0 & 0 & 0 & 0 & 1 & 96 \\
\hline IBEDROLA & Europe & utilities & 0 & 0 & 0 & 1 & 0 & 459 \\
\hline NOVO NORDISK & Europe & healthcare & 1 & 1 & 1 & 0 & 1 & 121 \\
\hline TATA STEEL & Asia & industrials & 0 & 0 & 0 & 0 & 0 & 300 \\
\hline
\end{tabular}

Source: the author's research.

The data presented in Table 2 indicate that, with the exception of Tata Steel (IR first disclosure in 2016, covering the period 2015-2016), all the entities have experience preparing reports in compliance with IIRC recommendations. Novo Nordisk has met its IR requirements five times despite naming its statement Annual Report (AR). Similarly, ING does not apply IR terminology in its ARs with the required elements. AXA and Diageo, though their 2016 statements complied with IR requirements, used IR terminology for the first time. All reports disclosed on IIRC's website by Coca-Cola Hallenic Bottling Company and Ibedrola are integrated reports which use the relevant terminology. The entities which present their IRs on IIRC's website and disclose the element "risks and opportunities" are European entities (except Tata Steel, based in Asia), representing five various sectors: consumer goods (Coca-Cola Hallenic Bottling Company, Diageo), financial services (AXA, ING), healthcare (Novo Nordisk), industrials (Tata Steel) and utilities (Ibedrola). Report length varied significantly, which can be attributed to company size and the scope of its activities. At 96 pages, Ibedrola's 
report was the shortest, while ING's was, at 459 pages, the most extensive. Even the most patient and knowledgeable of readers find it difficult to grasp the entire content of IR information, which is an issue raised by IR practitioners (Integrated Reporting... 2017, p. 34-37).

The next stage of the analysis focuses on an in-depth verification of information contained in "risks and opportunities". An assessment of risk-related disclosures complying with IIRC requirements indicates that the relevant data meets the requirement in all of the cases analysed. The companies carry out a detailed analysis of the specific risks and opportunities which can impact their ability to create value in short-, mid- and long-term periods, incorporating them into their strategic plans, as well as activities related to the classified types of risk they identified.

To achieve the aims of this study, I carried out an in-depth analysis of business risk disclosures and identified risk types. The analysis focuses on the comprehensive versions of 2016 integrated reports, prepared and disclosed on IIRC's website by the entities presented in Table 3 . The data provided by the entities is systematised, which made it possible to identify the ten most frequently occurring types (sources) of risk the companies under analysis faced (Table 3).

Table 3. Types (Sources) of Risk Identified in IRs in 2016

\begin{tabular}{|l|c|c|}
\hline \multicolumn{1}{|c|}{ Type of Risk } & $\begin{array}{c}\text { Number of Entities } \\
\text { Identifying a Specific Risk }\end{array}$ & $\begin{array}{c}\text { Share (\%) } \\
\text { in the Total Number of IRs } \\
\text { Disclosing Content Element } \\
\text { "Risk and Opportunities" }\end{array}$ \\
\hline Exchange rate risks & 7 & 100 \\
\hline Interest rate risks & 6 & 85,71 \\
\hline Regulatory change risks & 6 & 85,71 \\
\hline Climate change risks & 6 & 85,71 \\
\hline Technology and cyber risks & 6 & 85,71 \\
\hline Tax risks & 5 & 71,43 \\
\hline Demographic change risks & 5 & 71,43 \\
\hline Social and political unrest & 4 & 57,14 \\
\hline Health risks & 4 & 57,14 \\
\hline Customer innovation risks & 3 & 42,86 \\
\hline
\end{tabular}

Source: the author's research.

All of the entities identified exchange rate risks, which result from their international business operations. The entities were also concerned about other types of risk including interest rate, regulatory change, climate change, technology and cyber risks, which were identified by $85.71 \%$ of the population. Interestingly, one 
entity (Tata Steel) regarded technology and cyber risks exclusively as opportunities. Interest rate risks are related to bank failures and the instability of the banking system. Concerns about climate change risks mainly concern the need to meet stricter environmental regulations, the unavoidable impact on the natural environment, climate change including global warming effects and obligations related to land rehabilitation programmes and waste utilisation. With regard to tax risks and demographic change risks, $71.43 \%$ of the entities analysed express concern about changes in local fiscal policies and the implementation of new fiscal mechanisms, as well as the need for adapting to the conditions of aging societies. Social and political unrest and health risks are identified by more than $57.14 \%$ of the population. Another concern relates to the threat of global terrorism and the increasing number of people's claims to their social rights. Three of the analysed entities cited customer innovation risks, resulting from customers' changing requirements.

A review of the study's results leads to the conclusion that the identification of types (sources) of risk presented in IRs confirms company executives' high awareness of risk-related issues exerting a positive impact on entities' image. In the context of widely circulated information about threats to business activities, this demonstrates the ability to identify phenomena inherent in their core activities. Identification of risk is presented by most entities in the form of risk maps, which show the scope and likelihood of threats, referencing them to the disclosures of internal and external respondents. Also, IRs describe trends for particular types of risk (increasing, decreasing or unchanging). Being aware of business risk, entities propose appropriate measures in response to the threats and current conditions they identify.

\section{Concluding Remarks}

Integrated reporting poses a great challenge to accounting and identifies new areas of activities which deserve in-depth analyses. In the context of the benefits resulting from integrated reporting, attention should also be given to possible threats related to the presentation of data in accordance with IIRC proposals, especially non-financial information. Difficulties result from the assessment of the reliability of disclosures, the a measurement of which is very complex or sometimes impossible. Such a situation encourages researchers to analyse new issues, including those related to identifying risk.

The foregoing analysis confirms the hypothesis that an integrated report is a potential source of information that can be used to identify business risk. The problem is that integrated reports have got some weakness. First, the process of identifying relevant information is inefficient. Second, over a longer 
time horizon, the measurement of phenomena for the purpose of verifying and assessing external auditors is ineffective. To find solutions to the above problems, further research will be required to develop techniques and tools related to disclosures, and to keep abreast of new trends in integrated reporting. This process will be enhanced by implementing models for supporting the measurement of risk, adapted to the existing conditions.

\section{Bibliography}

Andrzejewski M. (2016), Sprawozdawczość i rewizja finansowa - czynniki determinujqce kierunki zmian w Polsce (in:) M. Andrzejewski (ed.), Ewolucja sprawozdawczości i rewizji finansowej w systemie rachunkowości, Difin, Warszawa.

Bek-Gaik B. (2015), Sprawozdawczość zintegrowana - wybrane problemy, "Zeszyty Naukowe Uniwersytetu Szczecińskiego. Finanse, Rynki Finansowe, Ubezpieczenia" no 77.

Bek-Gaik B., Rymkiewicz B. (2015), Sprawozdawczość zintegrowana w praktyce polskich spótek giełdowych (in:) B. Micherda (ed.), Sprawozdawczość i rewizja finansowa. Uwarunkowania ekonomiczne, społeczne i regulacyjne, Wydawnictwo Uniwersytetu Ekonomicznego w Krakowie, Kraków.

Black J. (2008), Słownik ekonomii, Wydawnictwo Naukowe PWN, Warszawa.

Bromiley P., Miller K. D., Rau D. (2001), Risk in Strategic Management Research (in:) M. A. Hitt, R. E. Freeman, J. S. Harison (eds), The Blackwell Handbook of Strategic Management, Blackwell Business, Oxford.

Brown J., Dillard J. (2014), Integrated Reporting: on the Need for Broadening out and Opening up, “Accounting, Auditing \& Accountability Journal", vol. 27, no 7, https:// doi.org/10.1108/aaaj-04-2013-1313.

Chłapek K. (2015), Pomiar ryzyka gospodarczego na podstawie sprawozdań finansowych, Difin, Warszawa.

Chłapek K. (2016), Identyfikacja ryzyka gospodarczego w sprawozdawczości zintegrowanej polskich spółek giełdowych (in:) M. Andrzejewski (ed.), Ewolucja sprawozdawczości i rewizji finansowej w systemie rachunkowości, Difin, Warszawa.

Dyrektywa Parlamentu Europejskiego i Rady 2014/95/UE z 22 października 2014 r. zmieniająca dyrektywę 2013/34/UE w odniesieniu do ujawniania informacji niefinansowych i informacji dotyczących różnorodności przez niektóre duże jednostki oraz grupy, http://eur-lex.europa.eu/legal-content/PL/TXT/?uri=uriserv\%3AOJ.L_.2014.330.01.0001.01.POL (accessed: 6.10.2016).

Eljasiak E. (2011), W kierunku zintegrowanej sprawozdawczości, “Zeszyty Teoretyczne Rachunkowości”, vol. 62(118).

Integrated Reporting: A Practical Perspective from Preparers and Practitioners (2017), "The CPA Journal“", July 2017, http://web.b.ebscohost.com.ebsco.han.uek.krakow. pl/ehost/pdfviewer/pdfviewer?vid=15\&sid=f380f516-05b1-458e-969f-276e2d7ab303\%40sessionmgr101 (accessed: 20.08.2017).

Integrated Reporting Moving towards Maturity. Are We Truly Maximizing the Benefits of Integrated Reporting? (2016), Deloitte, December 2016, https://www2.deloitte. 
com/content/dam/Deloitte/nl/Documents/risk/deloitte-nl-risk-integrated-reporting2016-def.pdf (accessed: 23.08.2017).

Jajuga K., Jajuga T. (1996), Inwestycje, PWN, Warszawa.

Karmańska A. (2008), Ryzyko w rachunkowości, Difin, Warszawa.

Kędzior M. (2016), Zintegrowana sprawozdawczość - próba oceny (in:) D. Adamek-

-Hyska, K. Tkocz-Wolny (eds), Współczesne problemy i kierunki transformacji rachunkowości i rewizji finansowej, Tom II, Aspekty zarzqdcze w rachunkowości, Wydawnictwo Uniwersytetu Ekonomicznego w Katowicach, Katowice.

Khattab A. A. (2011), The Role of Corporate Risk Managers in Country Risk Management: A Survey of Jordanian Multinational Enterprises, "International Journal of Business and Management", vol. 6, no 1, https:/www.researchgate.net/publication/49596193_ The_Role_of_Corporate_Risk_Managers_in_Country_Risk_Management_A_ Survey_of_Jordanian_Multinational_Enterprises (accessed: 23.08.2017).

Krasodomska J. (2015), Sprawozdawczość zintegrowana, jako nowy obszar badań naukowych w rachunkowości, "Zeszyty Teoretyczne Rachunkowości”, vol. 82(138), https:// www.icgn.org (accessed: 19.08.2017).

Kraten M. (2017), Transforming Integrated Reporting into Integrated Information Management: A Proposal for Management Accountants, “The CPA Journal”, July, http://web.b.ebscohost.com.ebsco.han.uek.krakow.pl/ehost/pdfviewer/pdfviewer?vi$\mathrm{d}=5 \& \mathrm{sid}=\mathrm{f} 380 \mathrm{f} 516-05 \mathrm{~b} 1-458 \mathrm{e}-969 \mathrm{f}-276 \mathrm{e} 2 \mathrm{~d} 7 \mathrm{ab303 \%} 40$ sessionmgr101 (accessed: 20.08.2017).

Kwiecień M. (2016), Sprawozdanie zintegrowane - innowacja paradygmatów rachunkowości, “Zeszyty Teoretyczne Rachunkowości”, vol. 87(143).

Lai F. W., Azizan N. A., Samad M. F. A. (2009), Shareholder Value Creation through Enterprise Risk Management, "International Journal of Business Research", vol. 10, no 1.

Lambooy T., Hordijk R., Bijveld W. (2014), Communicating about Integrating Sustainability in Corporate Strategy: Motivations and Regulatory Environments of Integrated Reporting from a European and Dutch Perspective (in:) R. Tench, W. Sun, B. Jones (eds), Communicating Corporate Social Responsibility: Perspectives and Practice, "Critical Studies on Corporate Responsibility, Governance and Sustainability", vol. 6.

Mądrość Syracha czyli Eklezjastyk (1991), Pismo Święte Starego i Nowego Testamentu w przekładzie z języków oryginalnych, Wydawnictwo Pallottinum, Poznań.

Merchant K. A. (2012), ERM: Where to Go from Here, "Management Accounting, Journal of Accountancy", vol. 214, no 3.

Podstawy rachunkowości. Aspekty teoretyczne i praktyczne (2005), B. Micherda (ed.), Wydawnictwo Naukowe PWN, Warszawa.

Rogowski W., Michalczewski A. (2005), Zarzq̨dzanie ryzykiem w przedsięwzięciach inwestycyjnych: ryzyko walutowe i ryzyko stopy procentowej, Oficyna Ekonomiczna, Kraków.

Sikacz H. (2014), Raportowanie o ryzyku płynności w kontekście społecznej odpowiedzialności przedsiębiorstwa w wybranych grupach kapitałowych, "Zeszyty Naukowe Uniwersytetu Szczecińskiego. Finanse, Rynki Finansowe, Ubezpieczenia” no 65.

Szychta A. (2010), Budżetowanie kapitałowe: planowanie i ocena efektywności przedsięwzięć inwestycyjnych (in:) A. A. Jaruga, P. Kabalski, A. Szychta (eds), Rachunkowość zarzqdcza, Wolters Kluwer, Warszawa. 
The International IR Framework (2013), http://integratedreporting.org/wp-content/ uploads/2013/12/13-12-08-THE-INTERNATIONAL-IR-FRAMEWORK-2-1.pdf (accessed: 22.09.2016).

Urbanowska-Sojkin E. (2013), Ryzyko w wyborach strategicznych w przedsiębiorstwach, PWN, Warszawa.

Villiers Ch. de, Rinaldi L., Unerman J. (2014), Integrated Reporting: Insights, Gaps and an Agenda for Future Research, "Accounting, Auditing \& Accountability Journal", vol. 27, no 7, https://www.researchgate.net/publication/263418164_Integrated_Reporting_Insights_gaps_and_an_agenda_for_future_research (accessed: 15.08.2017).

Zarzqdzanie ryzykiem (2008), K. Jajuga (ed.) PWN, Warszawa.

Zicari A. (2014), Can One Report Be Reached? The Challenge of Integrating Different Perspectives on Corporate Performance (in:) R. Tench, W. Sun, B. Jones (eds), Communicating Corporate Social Responsibility: Perspectives and Practice, "Critical Studies on Corporate Responsibility, Governance and Sustainability”, vol. 6.

\section{Rodzaje ryzyka gospodarczego występujące w sprawozdawczości zintegrowanej}

(Streszczenie)

Celem artykułu jest wskazanie możliwości identyfikacji ryzyka gospodarczego na podstawie danych zawartych w sprawozdawczości zintegrowanej. Jako metodę badawczą zastosowano przegląd literatury krajowej i zagranicznej oraz przeprowadzono analizę empiryczną ujawnionych raportów zintegrowanych za rok 2016. Struktura raportów, zgodna z najnowszymi trendami oraz zaleceniami światowymi w zakresie raportowania zintegrowanego, potwierdziła założoną w artykule tezę. Podsumowanie rozważań stanowi zachętę do zainteresowania badaniami nad możliwością weryfikacji i oceny ujawnień w zakresie identyfikacji ryzyka zawartych w sprawozdawczości zintegrowanej.

Słowa kluczowe: sprawozdawczość zintegrowana, ryzyko gospodarcze, identyfikacja ryzyka gospodarczego, raport zintegrowany. 